\title{
Urgency and Development Priorities of Lifelong Learning in Latvia
}

\author{
Aija Sannikova*, Aina Dobele \\ Department of Entrepreneurship and Management, LLU
}

\begin{abstract}
Based on the indicator of GDP per capita and the plan of business environment improvement measures, the urgency of developing lifelong learning in Latvia is analysed. Changes in the educational level of residents and in the education of employed individuals and job seekers in the period 2006-2010 are researched. The experts' evaluation of the lifelong learning development alternative in Latvia was carried out using Analytic Hierarchy Process. The conclusions indicate that primarily the establishment of the lifelong education system in companies (priority assessment vector 0.322 ) should be developed.
\end{abstract}

Key words: Economic competitiveness, lifelong learning, unemployment, education level.

\section{Introduction}

The strategic goal of European countries is to shape their societies and economies based on knowledge and ideas, therefore the role of nonmaterial resources, mostly human capital, increases.

Human capital as a totality of qualities of labour affects the quality of human resources and increases the efficiency of investments and labour productivity in an economy. The knowledge and skills of individuals are one of the most important characteristics of it; therefore, lifelong learning plays a significant role in shaping human capital.

Lifelong learning is understood as progressive changes in education in a field determined by society, which includes both increase in the participation of residents in educational activities and measures that develop competences of residents in important fields for a country, a region, or a certain enterprise, as well as improve macro- and microeconomic indicators.

Restriction of resources demands their effective usage, therefore the fields in lifelong learning to be developed should be identified in order to maximally promote the implementation of interests of the groups involved, thus increasing the competitiveness of individuals and the country.

The aim of the research was to investigate the economic aspects of urgency of lifelong learning in Latvia and to identify the main priorities for its development.

The tasks of the research:

1) to assess the economic aspects of urgency of lifelong learning in Latvia;
2) to analyse the indicators of educational level for residents, employed individuals, and job seekers in Latvia;

3) to summarise the results of expert evaluations on developing lifelong learning in Latvia.

\section{Materials and Methods}

To achieve the research aim, the indicator of GDP per capita in Latvia was analysed, the country's economic development was assessed, and data of the Central Statistical Bureau of Latvia on the country's competitiveness, on the education of residents as well as on the distribution of employed individuals and job seekers by education was analysed. A methodology developed by the World Economic Forum for evaluation of the economic development and competitiveness of countries was used in the present research.

The results of an expert survey conducted in 2010 are summarised in the paper. Statistical processing methods, comparative analysis, and hierarchy analysis were employed for data processing.

To analyse the need for lifelong learning, the economic development level and competitiveness of Latvia, and the supply of and demand for labour in the labour market by educational level were studied.

The economic development level of Latvia and its regions was determined based on a methodology (Schwab, 2010) developed by economists of the World Economic Forum (hereinafter the WEF). Data of the Central Statistical Bureau of Latvia on GDP per capita in 2004-2010 were used for this purpose. The data obtained were converted into US dollars

\footnotetext{
* Corresponding author's email:

Aija.Sannikova@inbox.lv
} 
(according to the exchange rate set by the Bank of Latvia for a particular year), and the obtained result was assessed according to the economic development scale developed by the WEF.

\section{Results and Discussion}

The analysis showed that the national economy of Latvia was in the efficiency-driven stage of development in the period 2004-2006, and its most significant economic driving force was the productivity of the resources used. Countries with a GDP per capita within a range of USD 3000-9000 belong to this group (Schwab, 2010).

Productivity is calculated as a value of goods and services produced per unit of resources used. Productivity depends on the ability of an economy to efficiently exploit its resources of production, which really takes place at the level of enterprises. Changes in productivity affect labour cost per unit of output at enterprises (it is calculated as a ratio of labour cost and labour productivity). An increase in labour cost per unit of output indicates a decrease in the price competitiveness of a country, while a decrease leads to an increase in its competitiveness.

In the period 2007-2010, the Latvian economy was in transition from the efficiency- to innovationdriven stage of development, which certainly was a positive trend.

Among 139 countries in the world in 2010, Latvia was ranked in the group of those $15(10.8 \%$ of countries included in the study) countries whose economy moved into the innovation-driven stage of development. Estonia and Lithuania belonged to this group as well. However, if GDP in real prices in 2010 is compared among the developed countries (such as the USA, France, Ireland, Finland, etc.), where GDP per capita is greater than USD 17000, and Latvia with GDP per capita LVL 5688, one has to conclude that the GDP per capita of Latvia is only approaching the lowest level of that of developed countries (Finanšu ministrija, 2011).

The rank of countries was used for determining the weighs of three criteria groups in which 12 competitiveness indicators - pillars - were included, and in the result of calculation, a value of the Global Competitiveness Index (hereinafter the GCI) was obtained for every country. In the group of indicators for the competitiveness of a country, an indicator related to lifelong learning - higher education and training - was included.

In 2010, the competitiveness of Latvia was ranked in the 70th position (the GCI was 4.14), and it was the third lowest position among the EU-27 countries. Estonia was ranked in the 33rd position (the GCI was 4.61 ), and Lithuania - in the 47 th position (the GCI was 4.38).

One of the factors affecting the competitiveness of a country is higher education and training. This component had a rating of 4.81 (35th position) for Latvia in 2010, while Finland gained the highest ranking with a rating of 6.06 ( $1 \mathrm{st}$ position).

One can conclude that in terms of economic development, overall competitiveness and the criterion specifying higher education and training, Latvia's ratings are not high and their improvement requires additional efforts.

The new relations of production and the competitiveness of enterprises may not be successfully achieved without increasing the quality of available human resources and continuously obtaining new knowledge (Field, 2000), as differences in production development affect the productivity of production factors. In the plan of business environment improvement measures for 2012, the quality of human resources and labour market elasticity also belong to the factors that, to a great extent, stimulate activity in the economy and increase the competitiveness of Latvian enterprises. According to indicators of the Global Competitiveness Index, the lack of adequate labour, which worsened three times in 2012 compared with 2011 (Par uzñēmējdarbības ..., 2012), is one of the hindering factors in the development of a competitive economy. It points to a need to develop lifelong learning in order to raise the quality of human resources.

Researches show (Fadejeva \& Mel̦ihovs, 2009) that in the case of Latvia, the total productivity of production factors may be evaluated more correctly if the corrected labour exploitation value is considered according to labour quality characteristics, for instance, the level of lifelong learning and its structural change.

The development of professional and general skills necessary for the labour market is based on the existing system of lifelong learning, which includes formal education and the supply of skills development services being excluded from it. The leading role in this process is played by individuals who choose a particular strategy in obtaining skills and knowledge.

The demand for employees who gained a certain level of education in the labour market is differentiated and depends on the economic situation in the country, on the development of national industries, and on other factors, such as educational level of residents, 
Table 1

Percentage distribution of Latvian residents by education level in 1996-2010

\begin{tabular}{|c|c|c|c|c|c|c|c|c|c|c|}
\hline \multirow[b]{2}{*}{ Education } & \multirow[b]{2}{*}{1996} & \multirow[b]{2}{*}{2004} & \multirow[b]{2}{*}{2005} & \multirow[b]{2}{*}{2006} & \multirow[b]{2}{*}{2007} & \multirow[b]{2}{*}{2008} & \multirow[b]{2}{*}{2009} & \multicolumn{3}{|c|}{2010} \\
\hline & & & & & & & & $\partial^{0}$ & 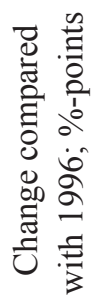 & 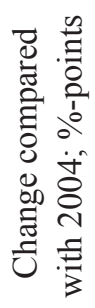 \\
\hline Higher education & 13.2 & 16.3 & 16.9 & 17.3 & 18.3 & 20.5 & 21.2 & 21.7 & 8.5 & 5.4 \\
\hline $\begin{array}{l}\text { Vocational or } \\
\text { professional } \\
\text { secondary } \\
\text { education }\end{array}$ & 35.0 & 31.5 & 31.0 & 31.3 & 30.1 & 30.2 & 30.4 & 31.4 & -3.6 & -0.1 \\
\hline $\begin{array}{l}\text { General } \\
\text { secondary } \\
\text { education }\end{array}$ & 20.6 & 24.8 & 25.0 & 24.7 & 25.5 & 24.8 & 25.5 & 25.6 & 5.0 & 0.8 \\
\hline $\begin{array}{l}\text { Primary } \\
\text { education }\end{array}$ & 20.5 & 22.5 & 22.6 & 22.3 & 21.6 & 20.4 & 19.5 & 18.4 & -2.1 & -4.1 \\
\hline $\begin{array}{l}\text { Lower than } \\
\text { primary } \\
\text { education }\end{array}$ & 10.7 & 4.9 & 4.6 & 4.4 & 4.3 & 4.1 & 3.3 & 2.8 & -7.9 & -2.1 \\
\hline Not specified & $\ldots$ & $\ldots$ & $\ldots$ & $\ldots$ & 0.2 & $\ldots$ & $\ldots$ & 0.1 & - & - \\
\hline
\end{tabular}

Source: based on data of the Central Statistical Bureau of Latvia (2012a).

supply of labour, etc.; it is affected by both objective economic processes and subjective opinions of employers on specifics of a job performed.

The quality of labour affects the economic development of a country and determines its competitiveness. Therefore, causal connections of demand and supply in the labour market of Latvia will be identified and distributions of Latvian residents, employed individuals, and job seekers by education level will be studied further in the research.

The analysis showed that in the distribution of Latvian residents by education (Table 1) in 19962010, the largest proportion was for residents who had gained vocational education and secondary professional education. This percentage distribution changed over time - in 2010 compared with 1996, a decrease of 3.6 percentage points was observed, while in 2010 compared with 2004, there was a decrease of 0.1 percentage points. In 2010, the second largest group was comprised of residents with general secondary education $(25.6 \%), 21.7 \%$ of residents had higher education, and the rest of residents $(21.3 \%)$ had primary or lower than primary education.
The following trends were observed in the demand for labour broken down by education level (Table 2) in the period 1996-2010:

- in the distribution of employed individuals in Latvia, the largest proportion consisted of employees with vocational education or professional secondary education $(35.4 \%$ in $2009 ; 35.8 \%$ in 2010);

It can be concluded that in the distribution of employees, the proportion of those with vocational education and professional secondary education in 2010 was lower than in 1996 (a decrease of 9.8 percentage points) and in 2004 (a decrease of 3.5 percentage points), and this decrease was greater than the decrease in the number of residents with vocational education and professional secondary education. It indicates that there is a disproportion between the demand for and supply of individuals with vocational education and professional secondary education.

- employed individuals with higher education were the second largest group (29.7\% in 2009 ; $30.7 \%$ in 2010); 
Percentage distribution of employed individuals by education level in Latvia in 1996-2010

\begin{tabular}{|c|c|c|c|c|c|c|c|c|c|c|}
\hline \multirow[b]{2}{*}{ Education } & \multirow[b]{2}{*}{1996} & \multirow[b]{2}{*}{2004} & \multirow[b]{2}{*}{2005} & \multirow[b]{2}{*}{2006} & \multirow[b]{2}{*}{2007} & \multirow[b]{2}{*}{2008} & \multirow[b]{2}{*}{2009} & \multicolumn{3}{|c|}{2010} \\
\hline & & & & & & & & $\partial^{0}$ & 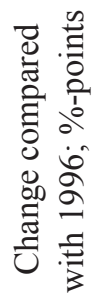 & 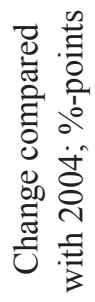 \\
\hline Higher education & 19.3 & 22.7 & 23.4 & 23.3 & 24.2 & 27.0 & 29.7 & 30.7 & 11.4 & 8.0 \\
\hline $\begin{array}{l}\text { Vocational or } \\
\text { professional } \\
\text { secondary } \\
\text { education }\end{array}$ & 45.6 & 39.3 & 37.5 & 37.3 & 35.4 & 35.5 & 35.4 & 35.8 & -9.8 & -3.5 \\
\hline $\begin{array}{l}\text { General secondary } \\
\text { education }\end{array}$ & 21.0 & 25.0 & 25.6 & 25.9 & 26.5 & 25.0 & 24.4 & 23.9 & 2.9 & -1.1 \\
\hline Primary education & 11.6 & 12.1 & 12.7 & 12.7 & 13.0 & 11.9 & 10.1 & 9.3 & -2.3 & -2.8 \\
\hline $\begin{array}{l}\text { Lower than } \\
\text { primary education }\end{array}$ & 2.5 & 0.8 & 0.8 & 0.8 & 0.6 & 0.6 & 0.3 & 0.3 & -2.2 & -0.5 \\
\hline Not specified & $\ldots$ & $\ldots$ & $\ldots$ & $\ldots$ & 0.3 & $\ldots$ & $\ldots$ & $\ldots$ & - & - \\
\hline
\end{tabular}

Source: based on data of the Central Statistical Bureau of Latvia (2012a).

In 2010 compared with 1996, the proportion of employed individuals with higher education rose by 11.4 percentage points and by 8.0 percentage points if compared with 2004.

- a large proportion of employed individuals in Latvia had no professional education (approximately $1 / 3$ of all employed individuals in Latvia!); there were $34.9 \%$ of such individuals in 2009 and $33.5 \%$ in 2010;

- a proportion of employed individuals with general secondary education in 2010 compared with 1996 declined by 2.9 percentage points and by 1.1 percentage points if compared with 2004 ;

- a proportion of employed individuals with primary education in 2010 compared with 1996 declined by 2.3 percentage points and by 2.8 percentage points if compared with 2004 .

Given the changes in the demand for labour in Latvia in the period 1996-2010 when the dominant trend was a dynamic increase in the number of employed individuals having higher education and also given the fact that a significant role in the national economy is played by employed individuals without professional education, an urgent issue is the change in the quality of labour.

After analysing the distribution of job seekers by education level in Latvia in 2005-2010
(Table 3), a paradoxical trend was revealed the largest proportion of job seekers consisted of individuals with vocational education and professional secondary education. The second largest group of job seekers was those with general secondary education, while the smallest groups were individuals with lower than primary education (it may be explained by the small proportion of this group in the total number of residents) and those with higher education. It means that the most significant prerequisite of competitiveness in Latvia is professional and general competencies which are higher for those with higher education compared with the other education groups of individuals, while competences of individuals with vocational education and professional secondary education in the period 2005-2010 were insufficient or inadequate, as the proportion of job seekers of this group was the largest. Of all job seekers in $2010,15.4 \%$ were individuals with higher education, $35.2 \%$ were those with vocational education and professional secondary education, $30.2 \%$ had secondary education, and $19.2 \%$ had primary and lower than primary education. These data stress the urgency of lifelong education in developing competences of labour according to the labour market demand. 
Percentage distribution of job seekers by education level in Latvia in 2004-2010

\begin{tabular}{|c|c|c|c|c|c|c|c|}
\hline \multirow[b]{2}{*}{ Education } & \multirow[b]{2}{*}{2005} & \multirow[b]{2}{*}{2006} & \multirow[b]{2}{*}{2007} & \multirow[b]{2}{*}{2008} & \multirow[b]{2}{*}{2009} & \multicolumn{2}{|r|}{2010} \\
\hline & & & & & & $\partial^{0}$ & 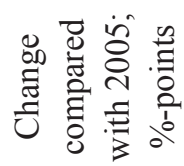 \\
\hline Higher education & 10.7 & 13.3 & 14.7 & 14.1 & 12.9 & 15.4 & 4.7 \\
\hline $\begin{array}{l}\text { Vocational or professional secondary } \\
\text { education }\end{array}$ & 36.4 & 31.7 & 33.4 & 32.7 & 34.2 & 35.2 & -1.2 \\
\hline General secondary education & 29.2 & 25.7 & 26.6 & 28.2 & 30.5 & 30.2 & 1.0 \\
\hline Primary education & 21.8 & 26.5 & 21.9 & 22.8 & 21.1 & 18.3 & -3.5 \\
\hline Lower than primary education & 1.9 & 2.8 & 3.4 & 2.2 & 1.3 & 0.9 & -1.0 \\
\hline
\end{tabular}

Source: based on data of the Central Statistical Bureau of Latvia (2012a).

Percentage distribution of Latvia's residents by education level in 2004 and 2011

\begin{tabular}{|c|c|c|c|c|c|}
\hline Region & Year & $\begin{array}{l}\text { Higher } \\
\text { education }\end{array}$ & $\begin{array}{c}\text { Vocational or } \\
\text { professional } \\
\text { secondary education }\end{array}$ & $\begin{array}{c}\text { General } \\
\text { secondary } \\
\text { education }\end{array}$ & $\begin{array}{c}\text { Primary or lower than } \\
\text { primary education }\end{array}$ \\
\hline \multirow{2}{*}{$\begin{array}{l}\text { Riga } \\
\text { region }\end{array}$} & 2004 & 25.5 & 32.5 & 24.8 & 17.3 \\
\hline & 2011 & 32.4 & 29.6 & 24.4 & 13.6 \\
\hline \multirow{2}{*}{$\begin{array}{l}\text { Pieriga } \\
\text { region }\end{array}$} & 2004 & 15.0 & 28.1 & 27.0 & 29.9 \\
\hline & 2011 & 23.5 & 29.3 & 26.0 & 21.2 \\
\hline \multirow{2}{*}{$\begin{array}{l}\text { Vidzeme } \\
\text { region }\end{array}$} & 2004 & 10.8 & 35.2 & 22.6 & 31.4 \\
\hline & 2011 & 14.8 & 33.9 & 23.2 & 28.0 \\
\hline \multirow{2}{*}{$\begin{array}{l}\text { Kurzeme } \\
\text { region }\end{array}$} & 2004 & 11.6 & 31.5 & 24.4 & 32.6 \\
\hline & 2011 & 18.0 & 30.4 & 24.1 & 27.5 \\
\hline \multirow{2}{*}{$\begin{array}{l}\text { Zemgale } \\
\text { region }\end{array}$} & 2004 & 9.4 & 29.7 & 25.6 & 35.3 \\
\hline & 2011 & 16.7 & 30.5 & 27.5 & 25.4 \\
\hline \multirow{2}{*}{$\begin{array}{l}\text { Latgale } \\
\text { region }\end{array}$} & 2004 & 11.7 & 31.9 & 23.6 & 32.8 \\
\hline & 2011 & 15.3 & 36.2 & 25.2 & 23.3 \\
\hline
\end{tabular}

Note. Data of 2011 correspond to the data of Population Census 2011.

Source: based on data of the Central Statistical Bureau of Latvia (2012b).

The quality of human resources affects the development of the national economy and serves as the most significant driving force in introducing innovations. The composition of residents by education is not homogenous in Latvia, and the population census of 2011, which reveals the distribution of individuals by education level in Latvian regions in 2011, proves it (Table 4). In Riga region in 2011, the largest group of residents with a proportion of $32.4 \%$ was individuals having higher education, while in the other regions of Latvia the largest group of residents comprised individuals with vocational education and professional secondary education. It means that the available and also potential labour resources in the regions of Latvia differ, which affects the development of the regions.

In order that the quality of labour resources meets the labour market demand, the skills of residents of all groups have to be continuously developed. In 1997, the European Commission and European Union member countries defined 
lifelong learning as all purposeful learning activity, undertaken on an ongoing basis with the aim of improving knowledge, skills and competence. Education and training assists in maintaining economic competitiveness and retaining occupation through the entire lifespan. Data of the Central Statistical Bureau of Latvia on the engagement of residents in lifelong learning in 2006-2011 show that employees with higher education composed the largest proportion among all lifelong learning participants aged 25-64. In 2011, 5.1\% of all individuals with higher education aged 25-64 participated in lifelong learning activities, while the same was observed for only $2.8 \%$ of those with vocational education and professional secondary education, $4.6 \%$ - with secondary education, and $1.9 \%$ - with primary education.

The research result allows for a conclusion that measures, which increase the quality of human resources, have to be taken in lifelong learning in Latvia.

Further in the research, based on the theoretical studies on the interaction of economic processes and lifelong learning done in the previous stages as well as a survey of specialists $(n=10$; the period 2009-2010), residents $(n=632$; the period 2009-2010), and employers $(n=160$; the period 2009-2010), the lifelong learning development alternatives were elaborated, and their expert evaluation (interviews of experts; $n=8$; the year 2010) was performed by employing the hierarchy analysis.

The developer of hierarchy analysis was American mathematician Thomas Saaty in the 1970s (Saaty, 1980). This method allows systemising information obtained during a study in a way that an optimal solution is identified for a problem to be tackled. In a hierarchy analysis, every variant of problem solution is assigned a rating and, therefore, a decision is made on choosing a variant that has gained the highest rating. A hierarchy analysis allows researching and assessing an identified problem very precisely as well as finding the most adequate solution, thus raising the quality of decisions made.

In the present research, the goal of the hierarchy analysis was to assess the effect of the lifelong learning development alternatives on interests of the groups researched as well as to determine the total rating of the alternatives in lifelong learning development.
To achieve the goal, a hierarchy pyramid (stages of rating), which included several levels, was constructed (Fig. 1):

- Level 1 - a goal;

At Level 1 of the pyramid, the highest goal "lifelong learning development in Latvia" - was defined.

- Level 2 - groups of criteria;

The groups of criteria were identified by asking a question, "To whom it is important that lifelong learning development is promoted in Latvia?"

The following four groups of criteria were chosen:

- interests of residents;

- interests of enterprises;

- interests of regions;

- national interests.

- Level 3 - criteria of rating (components of the groups of criteria);

At this level, components for the criteria group "interests of residents" were set based on the survey of residents, but those for the criteria group "interests of enterprises" were determined based on the survey of employers.

However, priorities in the interests of regions and national interests were determined based on a theoretical study on the components specifying regional and national socio-economic development and the interaction of lifelong learning and economic development.

To identify the criteria to be included in the criteria group "region" for the hierarchy pyramid, 10 employees from regions were interviewed. When asked a question, "What criteria, in your opinion, significantly indicate regional development and are related to lifelong learning development in Latvia?", the most often mentioned criteria were as follows:

- business development in the region - 8 responses;

- increase in employment -7 responses;

- availability of qualified labour -6 responses;

- foreign investments in the region -5 responses;

- improvement of the environment and infrastructure -4 responses, etc.

Three criteria which were mentioned more than five times by the respondents were selected.

The criteria included in the criteria group "national interests" were identified based on priorities set in Latvia's policy planning documents.

- Level 4 - alternatives in achieving the goal.

In Level 4 (the lowest), lifelong learning development variants (alternatives) which had to be rated by the experts in relation to the criteria of Levels 2 and 3 were included. The alternatives 

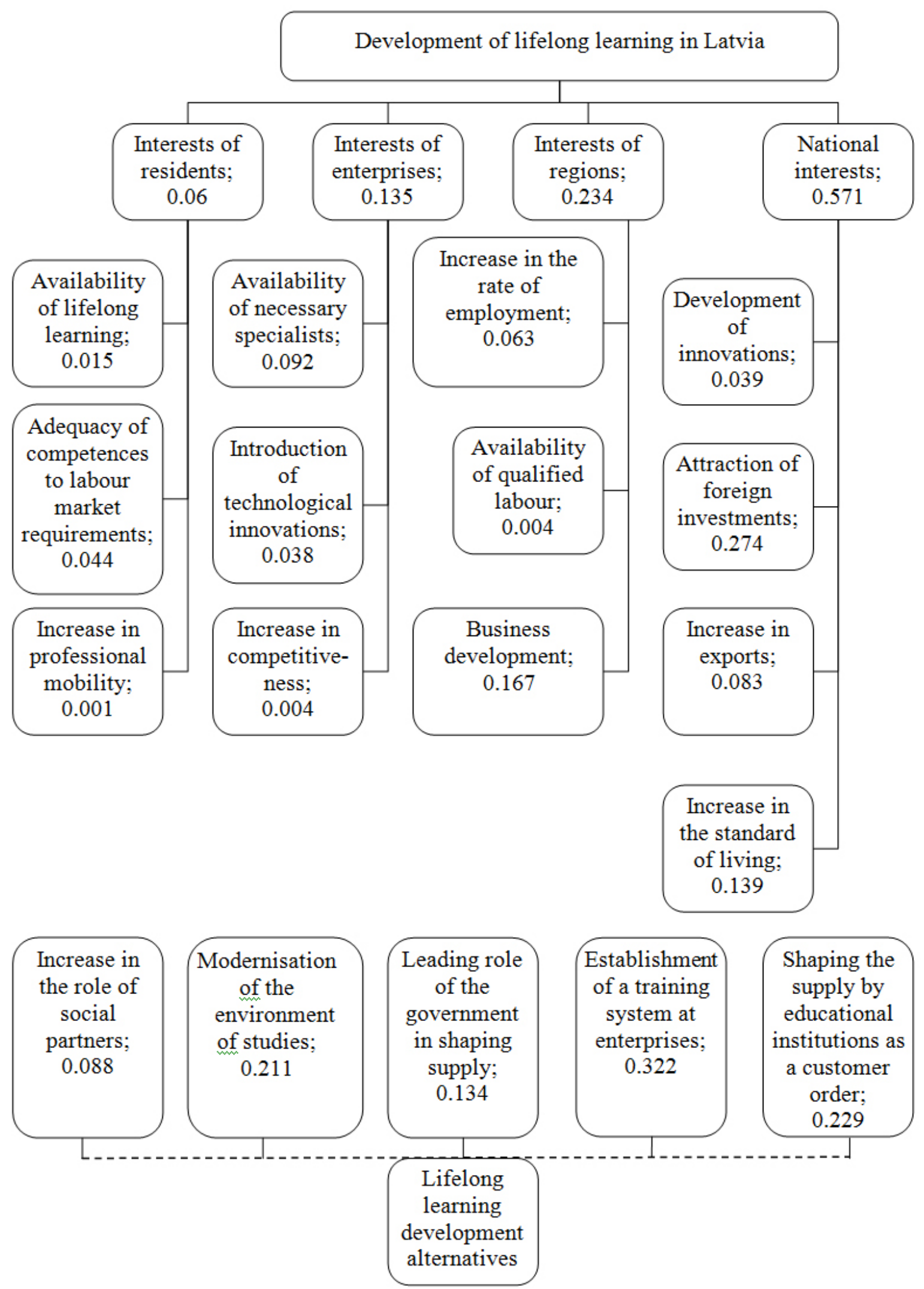

Fig. 1. Results of the evaluation of lifelong learning development alternatives in Latvia (2011-2012) using the method of analytic hierarchy. 
in achieving the goal were identified based on the survey of residents and employers and the priorities set in the policy planning documents on the development of human resources and lifelong learning.

After rating the criteria groups, priority vector coordinates, which were taken into account while determining the effect of a particular alternative, were obtained.

The highest ratings were obtained by:

- the criterion "adequacy of developed competences to labour market requirements" in the criteria group "interests of residents" (a rating of 0.044 );

- the criterion "availability of necessary specialists" in the criteria group "interests of enterprises" (a rating of 0.092);

- the criterion "business development" in the criteria group "interests of regions" (a rating of 0.167);

- the criterion "attraction of foreign investments" in the criteria group "national interests" (a rating of 0.274) (Fig.1).

The hierarchy analysis revealed that the most significant role in lifelong learning development in the present situation was played by the alternative "establishment of a training system at enterprises" its priority vector value was 0.322 .

The other alternatives obtained the following ratings:

- the alternative "shaping the supply by educational institutions as a customer order" - its priority vector value was 0.229 ;

- the alternative "modernization of the environment of studies" - its priority vector value was 0.211 ;

- the alternative "leading role of the government in shaping supply" - its priority vector value was 0.134 ;

- the alternative "increase in the role of social partners" - its priority vector value was 0.088 .

Establishing a training system at enterprises may include the introduction of mentoring approaches, the engagement of new employees in projects and working groups, and the organisation of practical training both for employees of enterprises and for students and residents who wish to individually develop certain skills, customer orders to educational institutions, etc. To assess the present situation in this field, a detailed research has to be performed; it would enable detailing the areas and a mechanism for introducing the alternative and would promote the establishment of cooperation among enterprises, educational institutions and other groups, as well as partnership in developing the alternative of lifelong learning.

\section{Conclusions}

1. The need for lifelong learning is determined by the economic development level of Latvia which was in transition from the efficiency- to innovation-driven stage of development in 2010 as well as by its low competitiveness which is affected by the quality of human resources.

2. In the distribution of Latvian residents by education in 1996-2010, the largest proportion was observed for residents who have gained vocational education and secondary professional education, and this proportion decreased by 3.6 percentage points in 2010 compared with 1996. However, the proportion of residents with higher education increased both among employed individuals and residents, which indicates an increase in the role of higher education in the labour market.

3. The need for lifelong learning in Latvia is also determined by the large number of employed individuals without professional education $(33.5 \%$ in 2010$)$, which negatively affects labour productivity, and by the opinion of businessmen on the lack of adequate labour.

4. The analysis of job seekers in 1996-2010 showed that their distribution was not homogenous and the largest group consisted of residents with vocational education and secondary professional education, whereas the smallest one comprised those with higher education. This suggests that support is necessary for skills development in lifelong learning among all the education groups of residents.

5. Developing lifelong learning has to be related to changes in the society. Due to limited resources, it is useful to support such alternatives of development that contribute to the implementation of interests of all the groups involved. According to the expert ratings of the alternatives of lifelong learning, the alternative "establishment of a training system at enterprises" had the highest rating (the priority vector was 0.322 ); therefore, its development possibilities and introduction model should be studied in future researches. 


\section{References}

1. Central Statistical Bureau of Latvia. (2012a). IZG02 Enrolment of Education Institutions by Level of Education. Retrieved from http:// data.csb.gov.lv/Dialog/varval.asp?ma=IZ002 0a\&ti $=\mathrm{IZG} 02 \% 2 \mathrm{E}+\mathrm{ENROLMENT}+\mathrm{OF}+\mathrm{ED}$ UCATION+INSTITUTIONS+BY+LEVEL+ OF+EDUCATION\&path=../DATABASEEN/ Iedzsoc/Annual $\% 20$ statistical $\% 20$ data/09.\%20 Education/\&lang=1

2. Central Statistical Bureau of Latvia. (2012b). NBG35. Population by Labour Status, Education and Sex. Retrieved from http://data.csb.gov. lv/Dialog/varval.asp $? \mathrm{ma}=\mathrm{NB} 0350 \mathrm{a} \& \mathrm{ti}=\mathrm{NB}$ G35\%2E+POPULATION+BY+LABOUR+ STATUS\%2C+EDUCATION+AND+SEX\& path $=. . /$ DATABASEEN/Iedzsoc/Annual $\% 20$ statistical $\% 20$ data/05.\%20Employment $\% 20$ and $\% 20$ unemployment/\&lang=1

3. Fadejeva, L., \& Meḷihovs, A. (2009). Latvijas tautsaimniecības nozaru kopējās faktoru produktivitātes un faktoru izmantošanas novērtējums. Latvijas Bankas pētījums. Rīga: Latvijas Banka.

4. Field, J. (2000). Chapter 3: The learning economy. In Lifelong Learning and the New Educational Order (pp. 69-100). Stoke-onTrent: Trentham Books.

5. Finanšu ministrija. (2011). Latvijas Republikas 2010. gada pārskats par valsts budžeta izpildi un par pašvaldību budžetiem, 2. sēj. Rīga: Valsts Kase.

6. Par uzñèmējdarbības vides uzlabošanas pasākumu plānu 2012. gadam. (2012). Ministru kabineta 2012. gada 18. aprīḷa rīkojums Nr. 178. Retrieved from http://www.likumi.lv/body_ print.pht?id $=246716$

7. Saaty, T.L. (1980). The Analytic Hierarchy Process. New York: McGraw-Hill International.

8. Schwab, K. (Ed.). (2010). The Global Competitiveness Report 2010-2011. World Economic Forum, Geneva, Switzerland, 2010. Retrieved from http://www3.weforum.org/docs/ WEF_GlobalCompetitivenessReport_2010-11. pdf 